\title{
PERENCANAAN PENYEDIAAN DAYA LISTRIK BERBASIS TENAGA SURYA UNTUK PENERANGAN JALAN UMUM DI KAMPUS UNIVERSITAS BORNEO TARAKAN
}

\author{
Ashariansyah ${ }^{1}$, Achmad Budiman ${ }^{2}$ \\ ${ }^{1,2}$ Universitas Borneo Tarakan, Tarakan, Kalimantan Utara, Indonesia \\ ${ }^{1}$ anshariansyah@borneo.ac.id \\ 2achmad1177@gmail.com
}

\begin{abstract}
Very bright, energy-efficient and durable LEDbased solar street lighting using solar cells as a source that functions to receive sunlight which is then converted into electricity through the photovoltaic process. This paper discusses solar-based public street lighting planning that will be placed on the UBT campus. For planning, it requires solar panel components which include Solar Panels, Solar Modules, Batteries, Battery Chargers, Controllers, Inverters, LED Lights and UV LIGHT METERS. This research is about the study of PLTS development as a backup of electric power in the area of the Tarakan University of Borneo. The results obtained in planning Public street lighting is the measurement of sunlight for one week. the largest average measurement is around $722 \mathrm{~W} / \mathrm{m} 2$ and the smallest measurement is $678 \mathrm{~W} /$ m2. and using supporting device components, namely $200 \mathrm{Wp}$ Module as many as 75 solar panels, led lights load of 40 Watts with a total of 103 lights having a total led load of 4,120 Watts, 100 Ah Batteries as many as 108 units and battery Regulators of 223,17 $A$ and inverters used which is 7,000 W.
\end{abstract}

Keywords-Solar Cells, Solar Modules, Battery Chargers, Controllers, Led Lights, Uv Light Meters.

Intisari- Lampu penerangan jalan tenaga matahari berbasis LED jenis hi- power yang sangat terang, hemat energi dan tahan lama menggunakan panel surya/solar cell sebagai sumber yang berfungsi menerima sinar matahari yang kemudian diubah menjadi listrik melalui proses photovoltaic. Tulisan ini membahas tentang perencanaan penerangan jalan umum berbasis tenaga surya yang akan di tempatkan di kampus UBT. Untuk perencanaannya memerlukan komponen panel surya yang di antaranya adalah Panel Surya, Modul Surya, Baterai, Baterai Charger, Controller, Inverter, Lampu LED Dan UV LIGHT METER. Penelitian ini mengenai kajian pembangunan PLTS sebagai cadangan daya listrik di daerah Kampus universitas Borneo Tarakan. Hasil yang di peroleh dalam perencanaan Penerangan jalan umum yaitu pengukuran cahaya matahari selama satu minggu. nilai rata-rata pengukuran terbesar sekitar $722 \mathrm{~W} / \mathrm{m}^{2}$ dan pengukuran terkecil adalah $678 \mathrm{~W} / \mathrm{m}^{2}$. dan menggunakan komponen perangkat pendukung yaitu Modul 200 Wp sebanyak 75 panel surya, beban lampu led sebesar 40 Watt dengan total 103 lampu memiliki total beban led 4.120 Watt, Baterai 100 Ah sebanyak 108 unit dan Regulator baterai sebesar 223,17 A serta inverter yang di gunakan yaitu $7.000 \mathrm{~W}$.

Kata Kunci- Solar Cell, Modul Surya, Battery Charger, Controller, Lampu Led, Uv Light Meter.

\section{PENDAHULUAN}

Pemanfatan energi matahari merupakan sumber energi yang dapat di manfaatkan penerangan jalan di perkotaan maupun pedesaan. Lampu Jalan Tenaga Surya secara otomatis dapat mulai menyala pada sore hari dan padam pada pagi hari dengan perawatan yang mudah dan efisien selama bertahun-tahun.

Secara keseluruhan sistem ini dirancang untuk penyediaan cahaya penerangan umum dengan sumber energi terbarukan, bebas biaya perawatan dan berumur ekonomis lama[1]. Dengan sistem pemasangan yang cepat dan mudah, PJU LED Tenaga Surya dapat menjadi solusi yang cepat dalam mengatasi kebutuhan penerangan jalan umum. Penggunaan pembangkit listrik tenaga surya dapat menjadi alternafif untuk mengatasi permasalahan tersebut diatas karena potensinya yang cukup besar di seluruh daerah di Indonesia. PLTS dapat digunakan sebagai cadangan suplai daya listrik apabila terjadi gangguan pada suplai daya dari PLN. PLTS dapat digunakan langsung maupun melalui penyimpanan seperti baterai.

\section{LANDASAN TEORI}

\section{A. Penerangan Jalan Umum Tenaga Surya}

Lampu Penerangan Jalan Umum Tenaga Surya adalah lampu penerangan jalan yang menggunakan cahaya matahari sebagai sumber energi listriknya[2]. Penerangan Jalan Umum Tenaga Surya sangat cocok digunakan untuk jalan-jalan di daerah-daerah yang belum terjangkau oleh listrik PLN dan juga daerah-daerah yang mengalami krisis energi listrik terutama di daerah terpencil. Penerangan Jalan Tenaga Surya merupakan sebuah alternatif yang murah dan hemat untuk digunakan sebagai sumber listrik penerangan karena menggunakan sumber energi gratis dan tak terbatas dari alam yaitu energi matahari[3][4].

\section{B. Energi yang dihasilkan dari Radiasi Matahari}

Besarnya energi yang dihasilkan dari radiasi matahari yang masuk ke modul data ditentukan.

Dengan

$$
I_{r} \frac{\text { in } \times h}{\text { Standart test condition }}
$$

$\mathrm{I}_{r}:$ Intensitas radiasi matahari (watt $\left./ \mathrm{m} 2\right)$

$\mathrm{P}_{\text {in }}$ : Daya input radiasi matahari(Watt).

$1000 \mathrm{~W} / \mathrm{m}^{2}$ : Standart test condition.

Untuk mendapatkan kapasitas daya pada modul, yang diperlukan di dalam perhitungan adalah jumlah jam kerja 
bukan besarnya radiasi matahari, dibagi dengan standart test condition yaitu $1000 \mathrm{~W} / \mathrm{m} 2[5]$.

\section{Komponen PLTS}

- Solar Cell ( Panel Surya )

- Modul Surya

- Baterai Charger

- Solar PV Controller

- Inverter

- $\quad$ Lampu Led

- $\quad$ Alat Uv Light Meter.

D. Keuntungan Dan Rugi dari Pembangkit Listrik Tenaga Surya

1) Keuntungan PLTS

- Cahaya matahari merupakan energi yang dapat diperbaharui dan tidak akan habis.

- Pembangkit listrik tenaga surya merupakan pembangkit yang bersih dan ramah lingkungan.

- $\quad$ Sel surya relative panjang

- Panel surya tidak memberikan konstribusi terhadap polusi suara dan bekerja dengan sangat diam.

- Jika berdirinya PLTS ini di kampus UBT bisa di jadi kan bahan praktikum yang berhubungan dengan kuliah Pembangkit Listrik Tenaga Surya bagi Mahasiswa Teknik khususnya jurusan Teknik Elektro.

2) Rugi Pembangkit Listrik Tenaga Surya

Proses pembangkitan hanya dapat dilakukan pada siang hari. Lebih buruk lagi jika proses pembangkitan dilakukan pada musim penghujan serta bahan pembuatan komponen pembangkit listrik tenaga surya masih berharga mahal terutama untuk tipe sel fotovltaik.

\section{E. Perancangan Pembangkit Listrik Tenaga Surya}

1) Mencari total beban pemakaian per hari. persamaan yang digunakan adalah sebagai berikut:

Total Beban $(W h)=($ Daya $+30 \%) x$ Lama Pemakaian.

2) Menentukan ukuran kapasitas modul surya yang sesuai dengan beban pemakaian.

Jumlah jam kerja matahari :

$$
\frac{\text { radiast matahar } i \frac{w h}{m^{2}}}{1000 \frac{w}{m^{2}}}
$$

Dengan :

$1000 \mathrm{~W} / m^{2}=$ Standart test condition .

$$
C=\frac{E_{m}}{V_{B} \times D O D \times n_{\text {Total }}}
$$

$\mathrm{C}=$ Kapasitas baterai (Ah)

Em $=$ Energi total yang harus di suplai $(\mathrm{Wh})$

$\mathrm{VB}=$ Tegangan kerja baterai (Volt)

DOD $=$ Tingkat kedalaman pengosongan baterai $(\%)$

Пtotal $=$ Efisensi total sistem photovoltaic $(\%)$

4) Menentukan besar arus battery charger regulator

Dengan :

$$
I_{\text {maks }}=\frac{P_{\text {maks }}}{V_{s}}
$$

$I_{m a k s}=$ Arus Maksimal

$P_{\text {maks }}=$ Beban Maksimal

$V_{s}=$ Tegangan Sistem

\section{METODE PENELITIAN}

\section{A. Tempat dan Waktu pelaksanaan}

Pembangunan PLTS pada PJU di daerah Kampus Universitas Borneo Tarakan.

\section{B. Strategi Pengembangannya}

Penelitian ini merupakan penelitian yang baru yang dilakuan di Kampus universitas Borneo Tarakan sehingga di perlukan pengambilan data secara langsung di lokasi tempat penelitian. Serta di lakukan perhitungan guna perancangan pembangkit listrik tenaga surya.

\section{Objek Penelitian}

Penelitian ini membahas mengenai PLTS sebagai cadangan daya listrik pada PJU di daerah Kampus Borneo Tarakan.

\section{Tahap Penelitian}

1. Pengumpulan Literatur

2. Studi kasus

3. Pengumpulan Data

4. Analisa Data

5. Kesimpulan

6. Alat Penelitian

7. Uv Light Meter

8. Laptop

E. Diagram Alur Penelitian

Kapasitas modul :

$$
\frac{\text { Beban pemakaian harian }}{\text { |umlah jam kerja matahari }} \times 1,1
$$

Menghitung jumlah modul yang akan dipakai Jumlah modul :

$$
\frac{\text { Daya Modul }}{\text { Kapasitas Modul }}
$$

3) Menentukan kapasitas baterai/Accu Persamaan yang digunakan adalah : 


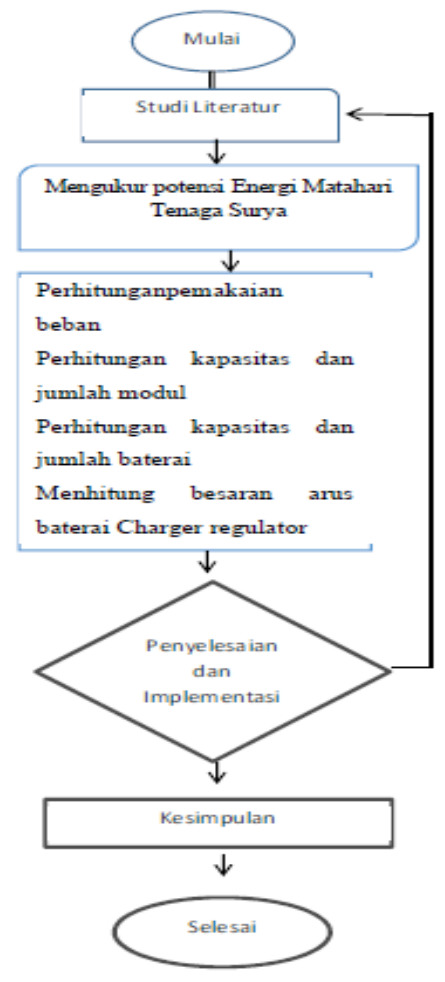

Gambar 1. Diagram Alur Penelitian

\section{F. Teknik dan perencanaan sistem penerangan}

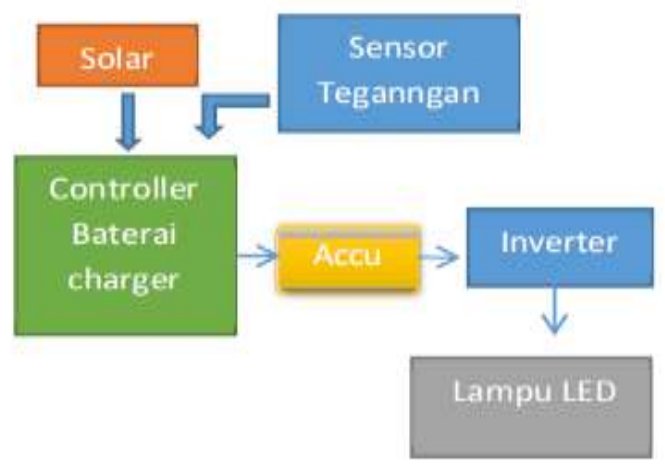

Gambar 2 Perencanaan sistem penerangan

Pada perencanaan dan pembuatan perangkat keras baterai charge dan lampu LED sebagai sumber lampu untuk kebutuhan beban Penerangan Jalan Umum.

Total daya yang digunakan untuk lampu penerangan jalan umum di areal kampus UBT:

1) Jumlah Titik Tiang : 65 TOT

2) Jumlah Titik Tiang : 19TOG

3) Sudut Stang Ornament :29,772 Derajat

4) Tinggi Tiang : 7 Meter

5) Jumlah total lampu :103 bohlam

6) P total daya lampu : 4.120Watt

7) Iluminasi (Lux) :1,752 Lux

8) Waktu beroperasi : 12 jam

- Menyala :Pukul 18.00 WITA

- Padam :Pukul 06.00 WITA
Untuk mengetahui hasil dari total daya lampu maka,

$\mathrm{P}:$ Watt $\mathrm{x}(\mathrm{TOT}+(2 \times \mathrm{TOG}))$

$$
\begin{aligned}
& : 40 \times(65+(2 \times 19)) \\
& : 40 \times 103 \\
& : 4.120 \text { Watt }
\end{aligned}
$$

\section{HASIL DAN PEMBAHASAN}

\section{A. Mengetahui hasil total daya lampu dan pemakaian} listrik.

Untuk mengetahui hasil dari total daya lampu maka,

$\mathrm{P}=$ Watt $\mathrm{x}(\mathrm{TOT}+(2 \times$ TOG $))$

$40 \times(65+(2 \times 19))$

$40 \times 103=4.120$ Watt

Menentukan Pemakaian Listrik Per Hari

$\mathrm{P}=($ Total beban Watt $+30 \%) \mathrm{x}$ jam pemakaian

$(4.120 \mathrm{~W}+30 \%) \times 12$ jam

$(4.120 \mathrm{~W}+1.236) \times 12 \mathrm{jam}$

$5.356 \mathrm{~W} \times 12 \mathrm{jam}=64.272 \mathrm{Wh}$

\section{B. Perencanaan pada Sistem Fotovoltaik}

Berdasarkan karakteristik beban dan kondisi yang ada. Perancangan yang dilakukan pada subbab ini terdiri dari pengukuran radiasi matahari perancangan modul photovoltaic, perencanaan baterai, perancangan battery control regulator perencanaan inverter, dan perencanaan lampu LED. Hasil Pengukuran Radiasi Matahari.

Tabel 1 Nilai rata-rata intensitas cahaya matahari selama satu minggu.

\begin{tabular}{|c|l|c|c|}
\hline \multirow{2}{*}{ No } & \multirow{2}{*}{ Hari/Tanggal } & \multicolumn{2}{|c|}{$\begin{array}{c}\text { Rata-Rata Intensitas } \\
\text { cahaya Matahari } \\
\left(\mathrm{W} / \mathrm{m}^{2}\right)\end{array}$} \\
\cline { 3 - 4 } & & $\begin{array}{c}\text { Min } \\
\left(\mathrm{w} / \mathrm{m}^{2}\right)\end{array}$ & $\begin{array}{c}\text { Max } \\
\left(\mathrm{w} / \mathrm{m}^{2}\right)\end{array}$ \\
\hline 1 & Kamis 27/07/2017 & 690 & 728 \\
\hline 2 & Jumat 28/07/2017 & 685 & 788 \\
\hline 3 & Sabtu 29/07/2017 & 618 & 669 \\
\hline 4 & Minggu 30/07/2017 & 735 & 760 \\
\hline 5 & Senin 31/07/2017 & 529 & 572 \\
\hline 6 & Selasa 01/08/2017 & 780 & 817 \\
\hline 7 & Rabu 02/08/2017 & 710 & 721 \\
\hline & Rata-rata & 678 & 722 \\
\hline
\end{tabular}

Dan dari tabel diatas dapat dilihat nilai rata-rata maksimal intensitas cahaya matahari selama satu minggu sebesar $722 \mathrm{~W} / \mathrm{m}^{2}$ sedangkan nilai minimal intensitas cahaya matahari selama satu minggu adalah $678 \mathrm{~W} / \mathrm{m}^{2}$.

\section{Keterangan Tabel}

Tabel diberi nomor menggunakan angka romawi huruf besar. Keterangan tabel di tengah (centered) dengan font biasa berukuran 10 pt dengan huruf besar di awal kalimat. Keterangan tabel ditempatkan dibawah nomor Tabel, seperti yang ditunjukkan pada Tabel 1 .

\section{Menentukan Kapasitas dan Jumlah Modul}

Untuk menentukan kapasitas daya modul surya diambil berdasarkan nilai rata-rata pengukuran energi matahari. 


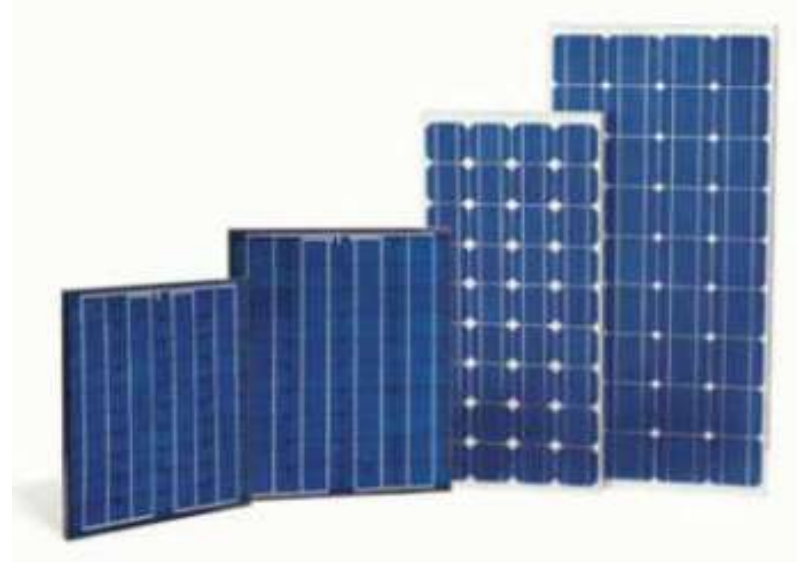

Gambar 3. Panel Surya (Sollar Cell)

Untuk kondisi penyinaran matahari di kampus UBT. dari nilai rata-rata intensitas matahari tersebut kita mencari nilai radiasi matahari dengan mengalikan nilai intensitas cahaya matahari Pada perhitungan menggunakan nilai intensitas matahari terendah selama 9 jam yaitu sekitar jam 08:00 sampai 17:00.

Radiasi matahari $=\mathrm{P}_{\text {in }} \mathrm{x}$ Waktu efektif

$=529 \mathrm{~W} / \mathrm{m}^{2} \times 9 \mathrm{~h}$

$=4.761 \mathrm{Wh} / \mathrm{m}^{2}$

Dan untuk mencari jam kerja matahari dapat dengan membagikan besaran nilai radiasi matahari dengan standart test condition yaitu $1.000 \mathrm{~W} / \mathrm{m}^{2}$.

Jumlah jam kerja matahari (h).

$$
\begin{aligned}
& =\frac{\text { radiasi matahari } \frac{w^{\text {h }}}{m^{2}}}{1000 \frac{w}{m^{2}}} \\
& =\frac{4761 \frac{w^{n}}{m^{2}}}{1000 \frac{w}{m^{2}}}
\end{aligned}
$$$$
=4761 \mathrm{~h}
$$

Untuk mencari besarnya nilai kapasitas yang dibutuhkan oleh modul dapat dicari dengan membagikan besarnya total beban dengan jumlah jam kerja matahari dan dikalikan dengan faktor penyusutan sebesar 1,1 .

Kapasitas modul $(W)$ :

$=\frac{\text { beban pemakaian }(W h)}{\text { Jumlah kerja matahari }(h)} \times 1_{x} 1$

$=\frac{64.272(\mathrm{Wh})}{4,761(h)} \times 1,1$

$$
=14.850 \mathrm{~W}
$$

Kemudian setelah mendapat besar kapasitas modul yang di butuhkan maka untuk mencari jumlah modul yang akan di pakai dapat dihitung dengan membagikan kapasitas modul yang butuhkan dengan daya modul yang di pergunakan.

$$
\begin{aligned}
& \text { Jumlah modul }=\frac{\text { daya modul }(\mathrm{W})}{\text { kapasitas modul }(\mathrm{Wp})} \\
& =\frac{14.850 \mathrm{~W}}{200 \mathrm{Wp}} \\
& =75 \text { panel }
\end{aligned}
$$

Jadi, jumlah panel yang di pergunakan sebagai cadangan daya pada pju untuk mengantikan suplai daya utama dari PLN dengan beban daya sebesar 5.356 watt dalam sejumlah 75 buah panel.

\section{Menentukan Kapasitas dan Jumlah Baterai}

Untuk menentukan kapasitas baterai harus mengetahui total beban yang akan di tanggung. dalam hal ini total beban yang akan di tanggung adalah sebesar 64.272 Wh. Jadi untuk menentukan nilai kapasitas baterai yang akan digunakan sebagai cadangan daya adalah dengan membagikan beban total dengan tegangan kerja pada baterai, tingkat kekosongan baterai dan efesiensi total sistem PV.

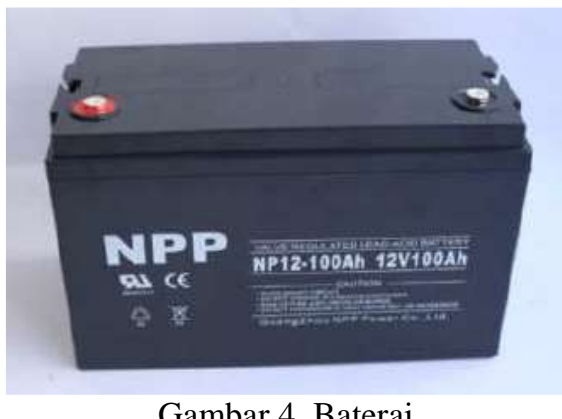

Gambar 4. Baterai

Menentukan nilai kapasitas baterai :

$$
\begin{aligned}
& C=\frac{E_{m}}{V_{B} \times D O D \times \eta_{\text {Total }}} \\
& =\frac{64.272 \mathrm{Wh}}{24 \mathrm{~V} \times 50 \% \times 50 \%} \\
& =10.712 \mathrm{Ah}
\end{aligned}
$$

Untuk menentukan jumlah baterai yang akan di gunakan maka dapat di cari dengan mebagikan kapasitas baterai yang di butuhkan dengan dengan kapasitas baterai yang di pakai.

$$
\begin{aligned}
\text { Jumlah baterai } & =\frac{\text { Kapasitas baterai dibutuhkan }(\mathrm{Ah})}{\text { kapasitas baterai di pakai }(\mathrm{Ah})} \\
& =108 \text { unit }
\end{aligned}
$$

Jadi, jumlah baterai yang digunakan sebagai cadangan daya pada Pju adalah sejumlah 108 unit. 


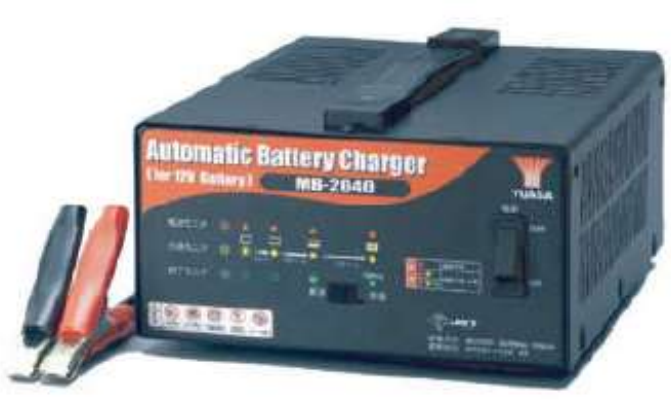

Gambar 5. Baterai Charger

Untuk menentukan besaran arus yang akan di gunakan adalah dengan menbagikan daya modul yang di gunakan dengan tegangan sistem.

$$
\begin{aligned}
I_{\text {mahs }} & =\frac{E_{\text {maks }} W}{V_{s}} \\
& =\frac{5.356 \mathrm{~W}}{24 \mathrm{~V}} \\
& =223,17 \mathrm{~A}
\end{aligned}
$$

\section{E. Menentukan Inverter yang Dipakai}

Spesifikasi inverter harus sesuai dengan tegangan kerja dari sistem dan tegangan pada beban AC. Berdasarkan tegangan sistem maka tegangan masuk dari inverter 48 VDC.

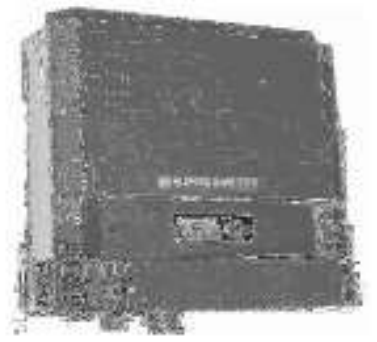

Gambar 6. Inverter

Tegangan keluaran dari inverter yang tersambung ke beban adalah 220 VAC.Berdasarkan perhitungan daya yang diperlukan maka kapasitas inveter yang di gunakan.

kapasitas inverter :

$$
\begin{aligned}
& =\text { beban total x } 1,3 \\
& =5.356 \mathrm{~W} \times 1,3 \\
& =6.962,8=7.000 \mathrm{~W}
\end{aligned}
$$

\section{KESIMPULAN}

Kesimpulan dari sebuah penelitian serta hitungan daya dalam PJU-TS di Area kampus UBT.

A. Dalam sebuah perencenaan PJU yang berbasis Tenaga Surya membutuhkan perkiraan Area luas yang kosong dengan panjang 40 meter dan lebar sekitar 40 meter .

B. Dari hasil pengukuran intesitas cahaya matahari dalam satu minggu nilai rata-rata pengukuran terbesar sekitar $722 \mathrm{~W} / \mathrm{m} 2$ dan pengukuran terkecil adalah $678 \mathrm{~W} / \mathrm{m} 2$.

C. Dan untuk penyimpanan atau suplai daya sebuah PJU (Penerangan Jalan Umum ) yang berbasis Tenaga Surya maka di perlukan komponen perangkat pendukung, yaitu Modul $200 \mathrm{Wp}$ sebanyak 75 panel surya , beban lampu led sebesar 40 Watt dengan total 103 lampu memiliki total beban led 4.120 Watt, Baterai 100 Ah sebanyak 108 unit dan Regulator baterai sebesar 223,17A serta inverter yang di gunakan yaitu $7.000 \mathrm{~W}$.

\section{SARAN}

Dengan ada nya sebuah ide dan pemikiran perencenaan mensuplai daya tenaga surya dari PJU di kampus UBT serta melihat potensi area yang sangat luas dan potensi intesitas cahaya matahari maka pemanfaatan energi tenaga surya menjadi sebuah perencenaan . selain itu dari penulis menyadari memiliki kekurangan yang sangat banyak maka bimbingan serta lanjutan penelitian mengenai PJU ( Penerangan Jalan Umum ) Berabasis tenaga Surya menjadi sebuah kelengkapan bagi Skripsi yang berjudul Perencanaan Penyediaan Daya Listrik Berbasis Tenaga Surya Untuk Penerangan Jalan Umum Di Kampus Universitas Borneo Tarakan.

\section{REFERENSI}

[1] Donny T B Sihombing, Ir. Surya Tarmizi Kasim Msi Konsentrasi Teknik Energi, Departemen Teknik Elektro Fakultas Teknik Universitas Sumatera Utara (USU)

[2] Gunardi Yudhi, "Perancangan Dan Pembuatan Pembangkit Listrik TenagaMatahari Untuk Lampu Penerangan Jalan", Jurusan Teknik Elektro Universitas Mercu Buana Jakarta, 2010.

[3] Hasnawiya Hasan "Perancangan Pembangkit Listrik Tenaga Surya Di Pulau Saugi", Jurusan Teknik Perkapalan - Fakultas Teknik, Universitas Hasanuddin J1. Perintis Kemerdekaan Km. 10 Tamalanrea - Makassar,Sulsel 90245.

[4] Rusminto Tjatur W, "Solar Cell Sumber Energi masa depan yang ramah Lingkungan", Jakarta: Berita Iptek, 2003.

[5] Suparwiyono (2016) Kajian Penggunaan pembangkit Listrik Tenaga Surya (PLTS) Sebagai Cadangan Daya Listrik Padabase Transceiver Station (BTS) Pantai Amal di Kota Tarakan. Tarakan : Universitas Borneo Tarakan.

[6] Immanuel, David. Pembangkit Listrik Tenaga Surya, diakses pada 26 Maret 2014,

[7] (2014) gdm energy homepage on [Online]. Available: http://gdmenergy.com/datasolusi/penerangan-jalanUmum-tenaga-suryapjuts-20W-tiang-6m.html

[8] (2014) indo energi homepage on [online]. Available : http://www.indoenergi.com/2012/04/keunggulandan-kelemahan-panelsurya.html 